\title{
Contested claims to social welfare: Basic income grants in Namibia ${ }^{1}$
}

\author{
Sabine KLOCKE-DAFFA ${ }^{2}$ \\ University of Tübingen
}

\begin{abstract}
In many parts of the world, income transfers to underprivileged groups have long been part of social welfare programmes. However, the conditionality of such grants has recently been challenged on a global scale, arguing that income grants should serve as a mechanism to redistribute national resources rather than filling the social gap, and be conceded to all members of the population. The only country that tested this kind of social policy is Namibia with its Basic Income Grant project (BIG). Ever since its launch in 2007, there has been a heated nation-and even worldwide debate concerning the pros and cons of an unconditional grant. This paper presents the results of an anthropological research, showing that in discussion on poverty reduction and the "rightful share" for the needy, the cultural factors governing decision making on the micro level have so far been neglected.

Keywords: anthropology, unconditional basic income grants, social welfare, giving and sharing, gift economy, distributional model, poverty reduction, rightful share, short-term exchanges, long-term exchanges, Namibia, Otjivero, Witvlei, ELCRN, Basic Income Grant Namibia (BIG)
\end{abstract}

\section{The Basic Income Grant (BIG) debate - some introductory remarks}

In many parts of the world, income transfers to underprivileged groups have long been part of social welfare regimes. In fact, many nation states and their governments derive part of their legitimacy from the degree of security and support they manage to procure for their populations since social security was declared a human right in the Declaration of Human Rights accepted by the United Nations in 1948 (Van Langendonck 2007). Citizens of ratifying states can thus claim a legal right to be protected against the perils of social or economic hazards brought about by their governments. On a global scale, the model of the welfare state became

\footnotetext{
${ }^{1}$ I am grateful to the Fritz-Thyssen-Foundation for generously supporting my research project on "Basic income and social security in Namibia" in 2011 and to Manja Stutzriemer for her invaluable support conducting the questionnaire campaign in Otjivero and Witvlei. Sincere gratitude is also expressed to the Collaborative Research Center SFB 1070 ResourceCultures funded by the German Research Foundation sponsoring my participation in the Windhoek Summer School 2014 on Cultural Heritage at the University Center for Studies in Namibia which allowed for a re-visit to the site of the Namibian Basic Income Project to update my data.

${ }^{2}$ PD Dr. Sabine Klocke-Daffa, Anthropologist, Institute of Asian and Oriental Studies/Department of Social and Cultural Anthropology, member of the Corporate Research Center ResourceCultures, University of Tuebingen/Germany. sabine.klocke-daffa@ethno.uni-tuebingen.de
} 
a powerful instrument of political legitimacy even in problematic states with imperfect markets where most people have to rely on informal relationships and personal networks (for comparison see Wood/Gough 2006). Income transfers are certainly not a marker of rich capitalist western countries. From anthropological studies we know that redistributive mechanisms for the sake of security are an integral part of any social organisation (most notably in Polynesia and Micronesia, see e.g. Petersen 1986; Robineau 1988). However, not even in gift economies ${ }^{3}$ is individual neediness a general prerequisite for receiving social benefits nor are one-way-transfers generally conceptualised as detrimental to economic prosperity (see contributions by Patterson 2012; Yan 2012; Hunt 2012).

Yet, what does seem to be characteristic of capitalist western countries is the concept of the self-referring individual trying to satisfy own needs if not otherwise satisfied. It is argued that people would be discouraged from working if all the basics of life were provided for, and lazy individuals would make a nation poor - so they should keep working (if not handicapped). The 18th century forefathers of classical economic theory like Adam Smith or David Ricardo successfully promoted the idea that boosting incentives for individuals would increase general productivity and national wellbeing in general - even though not necessarily for the working classes at that time. But it became common knowledge that it should be the individual - at best supported by close kin - who should be responsible for his or her own livelihood and only in case of emergency should society represented by the nation state step in. What did prevail was the idea that a materially wealthy nation must make continuous effort to provide for ample work opportunities - for the benefit of the state as well as for the material and social benefit of its citizens. Where work is not available or individuals fail to provide for their own advancement, the state must support individuals through income transfers to bridge temporary or permanent shortfalls. The decades-old discussion on the best solution to reduce poverty revolves around two options: universalism versus targeting, with the entire population being the beneficiary of social benefits or only the targeted "truly deserving". Since the 1980s, targeted social policies have been favoured for various reasons both in western countries and in the Global South (van Oorschot 2002) which led to a "shift from welfare to workfare states" (Mkandawire 2005: 1). Most of these benefits - whether in cash or in kind - are now meanstested and granted to individuals in need, where the definition of "need" is following national living standards. Welfare programmes in the Global North are generally based on welldefined criteria as to what individuals may claim in order to have a decent quality of life, whereas most welfare programmes in the Global South have benefits that are clearly below the poverty line. Targeted social benefits are generally subject to rigid scrutiny to make sure reci-

\footnotetext{
${ }^{3}$ The term 'gift economy' refers to economic systems or subsystems, which are not primarily based on the accumulation of material wealth but of social wealth, on generosity and on reciprocity. David Cheal defines the gift economy as "a system of redundant transactions within a moral economy, which makes possible the extended reproduction of social relations" (Cheal 1988:19). Goods for gifting (material items, knowledge, services) must have a use-value for consumers and must be produced by those who provide them - hence the term 'gift economy'. Gift economies are not only characteristic of many of small scale, traditional societies or communities such as those participating in the famous North American potlatch or the Melanesian kula. There is also a growing segment of modern, globalised economies where goods of use-value are distributed as free gifts via universally accessible networks (a famous example is Wikipedia) by peer-to-peer processes. However, the notion of the gift (to be reciprocated) has been contrasted with the concept of the righteous share (not to be reciprocated) so that Widlok (2017) prefers the term "economy of sharing".
} 
pients benefit only as long as necessary and leave the scheme as soon as possible. In current discourses on the key allocation questions (who gets what and why), there is a striking common ground originating in the idea of the state being responsible towards its needy and deserving citizens who should be grateful and reciprocate generous gifts in appropriate ways. Any conditional welfare programme thus does not aim at a permanent redistribution of wealth nor is it conceptualised as a mechanism for the distribution of legitimate shares.

However, the conditionality of grants - and the targeting itself - has recently been challenged on a global scale by a number of national movements in Asia, Latin America, Africa and Europe as well as Canada, Finland, Germany and Switzerland ${ }^{4}$. Proponents of an unconditional grant argue that income grants should not just fill the social gap between different income groups but should serve as a mechanism to redistribute national resources and be conceded to all members of a given population without being means-tested as an unconditional income grant and part of a fair share of national wealth. This is one of the reasons why the Namibian Basic Income Grant (BIG) became so prominent, in particular in South Africa, and even ahead of its launch (Agüero 2006; Barchiesi 2007; Nattrass/Seekings 2005; Standing/Samson 2003; for an overview see Seekings/Matisonn 2012). It continued to be widely discussed though it officially ended in 2009 and the reduced bridging allowance paid thereafter stopped in 2014 (for a general overview of basic income initiatives on a global scale including the Namibian BIG see Murray/Pateman 2012; Niemann 2015; Van Parijs/Vanderborght 2017). In 2017, Finland became the first European country to launch a nationwide pilot scheme paying an unconditional monthly allowance of 560 EUR to 2000 unemployed citizens for a period of two years 5 . The Canadian province of Ontario has launched another Basic Income Pilot starting in spring 2017 that supplements the earnings of individuals whose incomes are below the poverty line (but only those) ${ }^{6}$. James Ferguson rightly pointed to the fact, that the global basic income movement not only adds another aspect to the discussion on universalism versus targeting in welfare regimes, but is of quite a different order by making a "claim for a due and proper share grounded in nothing more than membership in a national collective", and what he terms "the politics of the rightful share" (Ferguson 2015: 184).

The concepts for an unconditional basic income so far presented are following two different models: the humanitarian model is based on the idea that every member of a nation state should be granted a basic income serving as an instrument of social justice and "real freedom" (van Parijs 1992; 1995, 2000; see also Van Der Veen 1998; Motte et al 2010; Wright 2000), allowing for a life in dignity and social security as by equal access to national wealth. The economic model claims that an unconditional income grant would have a positive impact on local markets, reduce the administrative costs of existing social security systems and at the same time reduce labour costs, freeing employers from having to pay social security benefits, thus

\footnotetext{
${ }^{4}$ An overview of the global debate is provided by the Basic Income Earth Network, see Basic Income Earth Network: http://www.basicincome.org/bien/; for Brazil see Suplici 2003; for German initiatives, see Blaschke 2012; Osterkamp 2017; Basic Income initiative Germany, http://www.grundeinkommen.de; for the Basic income initiative Switzerland, see http://www.grundeinkommen.ch/.

${ }^{5}$ For the Finnish pilot scheme, which started in 2017 see http://www.kela.fi/web/en/basic-income-experiment-20172018; also Koistinen/Perkiö 2014.

${ }^{6}$ For the Canadian basic income see Forget 2012, for the current pilot scheme, which started in 2017 see http://basicincome.org/news/2017/03/ontario-canada-government-releases-results-consultations-basic-income-pilot/.
} 
resulting in the creation of more jobs (Straubhaar 2008). Both models neglect that cultural norms might be significant in the distribution of income transfers as well.

It is not my purpose to assess the huge discussion on deservingness (for an overview see Cavaillé 2015; van Oorschot/Roosma 2017). My intention rather is to suggest that we take additional steps to define what policies of the rightful share must entail and find answers to more detailed questions: How is our notion of social welfare challenged by social transfers conceptualised as a share citizens must be guaranteed rather than a gift generously granted, which then constitutes an obligation to reciprocate on the side of the beneficiary? Also, does the claim to a righteous share comprise the right to use this share according to own prevalence or will it be connected to expectations of the policy planners as to what seems to be a reasonable use of the money (which makes is implicitly conditional)? I argue that beyond individual preferences and negotiations, cultural norms play a decisive role in the appropriation of social transfers, which makes the outcome highly contestable. I further argue that gifting and sharing should nevertheless be placed on a continuum rather than to be defined in terms of a dichotomy as delineated by Thomas Widlok in his thought-provoking book on exchange and the economy of sharing (Widlok 2017) refining Woodburn's suggestion to re-conceptualise reciprocity (1998). Whether this argument does point to a cultural model in the sense of a specific distributional model of income transfers will be discussed later.

I will check my arguments looking from an anthropological point of view into the effects of the much contested Basic Income Grant project in Namibia termed the "world's first unconditional transfer programme" ever (Kaufmann 2010: 38) running from 2007-2009.

\section{BIG in Namibia - an anthropological inquiry}

\section{Outline of the project}

The Namibian Basic Income Grant (BIG) officially ended in 2009 but continued up to 2014 with a $20 \%$ reduced bridging allowance. It attracted worldwide attention and caused heated debates inside and outside the country among economists, politicians, sociologists and church representatives (for the history of the project and its result see Haarmann et al. 2008; Haarmann/Haarmann 2012; reports on the website bignam.org). At its launch, the Namibian BIG was presented to the national and international media as an instrument to meet the pressing social needs of the country by alleviating poverty, improve living conditions and reduce the unequal distribution of wealth within the country, thus following the humanitarian model. In fact, according to the international GINI Index Namibia - a vast country with many natural resources such as diamonds, gold and uranium - shows one of the highest income disparities in the world (Davies et al. 2009; UN Development Programme 2016a) ${ }^{7}$. More than $50 \%$ of a

\footnotetext{
${ }^{7}$ The information on income and wealth distribution varies according to dedicated statistical database and imputation procedures. The impact on the results might be quite substantial but does not modify them altogether. Thus, the Gini coefficient for Namibia changes from 0.61 (World Bank 2000) to 0,84 (Davies et al. 2009: 60) estimating income disparities in Namibia for the year 2000 (a value of 0 indicates perfect equality, a value of 1.0 perfect inequality). In both cases, Namibia ranged among the countries with the greatest income and wealth inequality in the world. The Gini coefficient for Namibia in 2016 is still ranging at 0.61 (UNDP 2016a).
} 
population of only about 2 million is living below the international poverty line ${ }^{8}$. It is made up of 12 ethnic groups, which is not much as compared to other African states. The organisers of the BIG scheme also followed an economic model pointing to the expected impact on the local markets and possible incentives for individuals allowing for economic initiatives. Despite the fact that the Namibian proponents of the project put humanitarian arguments to the fore, economic aspects dominated the discussion throughout the process, not least to calm down critics addressing the presumed costs.

There are three specifics of the Namibian BIG which should be kept in mind:

- It was based on a proposal by the Namibian Tax Commission (NAMAX) set up by the Namibian government in 2001, not by a foreign development agency, an NGO or UN organisations.

- BIG was conceptualised as an unconditional grant given to every citizen in the country, independent of age, gender, ethnic affiliation, income or other possessions, leaving out only those who already received social welfare such as old age pensions or other social benefits.

- BIG was meant to be not more than a subsidy to the cost of living (as opposed to most social welfare programmes): every beneficiary was to receive $100 \mathrm{~N} \$$ per month, the equivalent of 10 EUR or $12 \$$ US at the time.

This was very little money which never did allow for a decent living nor was it meant to do so, but was expected to make a difference nonetheless: in an average household with six to eight children plus two adults, the monthly BIG allowance would total $1000 \mathrm{~N} \$$, the equivalent of two salaries of a farm worker at the time BIG started.

However, the Namibian government did not follow the commission's proposals (see Namibian Tax Consortium 2002) and no consent was achieved in parliament. So the EvangelicalLutheran Church in the Republic of Namibia (ELCRN) spearheaded further steps and initiated through its Desk for Social Development (DfSD) an international conference which suggested to establish a Coalition of independent institutions of civil society later to be called the Basic Income Coalition (see figure 1) publically launched in 2005 (Haarmann/Haarmann 2012: 34). It was composed of delegates of the Council of Churches (CCN), the Namibian trade unions $(\mathrm{NUNW})^{9}$, the Namibian Non-Governmental Organizations Forum (NANGOF), the Namibian Network of AIDS Service Organizations (NANASO), the National Youth Service (NYC), the Church Alliance for Orphans (CAFO), the Legal Assistance Centre (LAC) and the Labour Resource and Research Institute (LaRRI). Working in close cooperation with the Namibian government, the aim of the Basic Income Coalition was to promote an unconditional basic income grant to all citizens of Namibia. Since the Namibian government turned out to be rather reluctant, the idea of a pilot project was discussed in 2006 as "to

\footnotetext{
${ }^{8}$ According to the United Nations Human Development Report of 2016, the percentage of the Namibian population living in „multidimensional poverty” is indicated by 44.9\% (UNDP 2016b). According to calculations of the Namibian Statistics Agency dating back to the year 2009/2010, figures are substantially lower with not more than $28.7 \%$ of the entire population below upper poverty line (Namibia Statistics Agency 2012)

${ }^{9}$ In 2010, the trade unions temporarily left the coalition due to internal disputes among the members of the NUNW executive committee. Since 2011, NUNW is again a member of the BIG Coalition.
} 
concretely show that a BIG can work and will indeed have the predicted positive effects on poverty alleviation and economic development" (bignam.org).

\section{Figure 1: Logo of the Basic Income Grant Coalition}

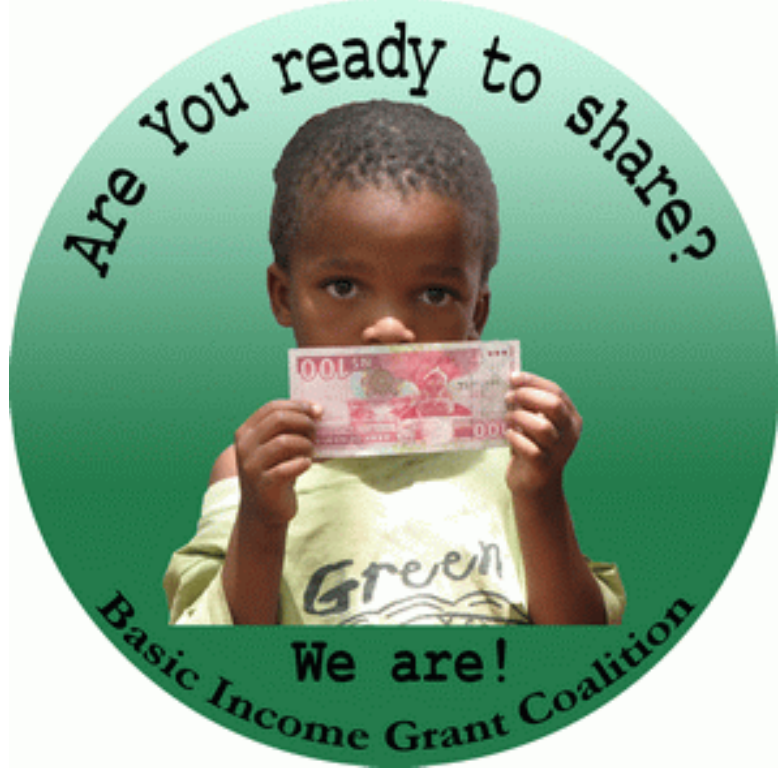

Source: http://www.bignam.org/BIG_pictures.html

After long debates about where to initiate an ambitious project like BIG, with all eyes focused on the outcome, and only a single location available in the entire country, it was eventually agreed upon to launch BIG in the small village of Otjivero, east of Namibia's capital Windhoek on the road to Gobabis (figure 2). ELCRN agreed to be responsible for the administrative and financial implementation of the project through its Desk for Social Development acting on behalf of the BIG Coalition (Haarmann et al. 2009: 18-19). Otjivero was at that time a settlement of about 900 inhabitants, most of them belonging to the Damara group, one of the 12 ethnic groups of the country and part of the Khoisan peoples of southern Africa. Initially, Otjivero was a so-called "wild settlement" set up by former farm workers who had lost their jobs and had no other place to go. They decided to settle on a strip of government owned land next to a water dam. The occupation was illegal but since the former farm workers' situation was desperate and there was no alternative in sight they went to court and eventually won a lawsuit which granted them the right to stay ${ }^{10}$.

However, besides the land (which they did not own) and the water there was not much else: no decent houses, no jobs, and no income - a "living example of hell on earth" as one of

\footnotetext{
${ }^{10}$ Seven commercial farmers of the Omitara area where Otjivero is situated approached the High Court to seek the squatters' eviction accusing the squatters of trespassing on their land. When the eviction was granted in 2001, members of SWAPO, the ruling party of Namibia, were publically threatening with "Zimbabwe-style land invasions" should the farmers proceed and encouraged Otjivero families to ignore the High Court eviction order. See Moyo/Tabby 2001: Namibia threatened with farm invasions. In: News Africa, 26.1.2001. online: https://www.iol.co.za/news/africa/namibia-threatened-withfarm-invasions-59347. Finally, the eviction order was stopped in 2001.
} 
the church pastors in Namibia once described it (Klöpper 2011, front page). After the village was officially recognised as a settlement, a school was established though facing high drop-out rates and a small clinic took care of the many HIV/AIDS patients.

Figure 2: The settlement of Otjivero, site of the BIG model project, is situated between Namibia's capital Windhoek and the eastern city of Gobabis.

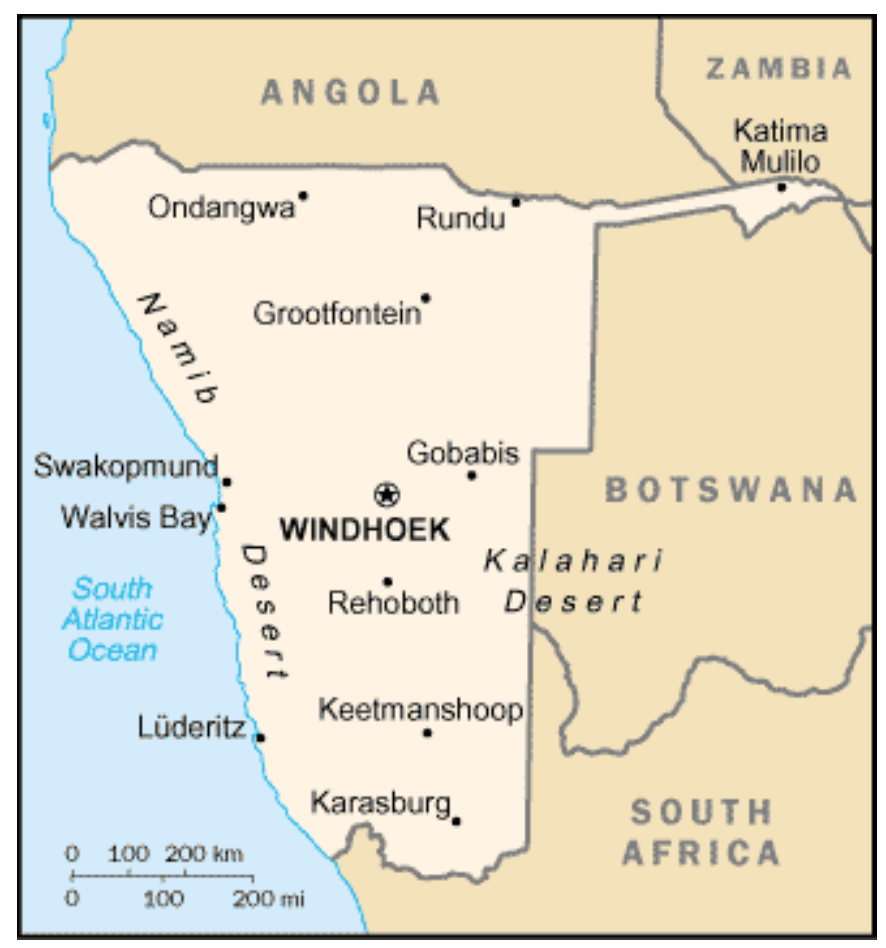

Source: https://commons.wikimedia.org

At the outset of BIG, the overall situation in Otjivero was even more desolate than in other poor areas of the country: $76 \%$ of the population was found to live below the poverty line, $2 / 3$ of all households did not have enough food and more than $40 \%$ of the children were malnourished (Haarmann et al. 2009: 15). Almost all Otjiverans lived in cramped tin houses with many children. An evaluation of the overall socio-economic situation was effected twice, once before and then again towards the end of the project. Unfortunately, no contrast group was included nor did cultural factors ever play a role in assessing the outcome of the model project.

Ultimately, it could be demonstrated that, as anticipated, social conditions had changed for the better: housing conditions had improved, people were better fed and in much better health. School attendance increased from $60-70 \%$ to almost $100 \%$ and the previously alarming crime rate dropped by 36.5\% (Haarmann et al. 2009: 46, 68). Undoubtedly, these results were much in favour of the project and might well have served to support the initial idea of a nationwide expansion of the Basic Income Grant.

However, two aims of the project could not be realised: 
1. The income per head of household did not increase but dropped due to a population gain of about $30 \%$ (mostly family members moving into Otjivero to stay with BIG recipients) and many households were still found impoverished.

2. Only a small number of people started businesses on their own or invested in other economic endeavours, and the reported savings rate of 37\% appeared more than unrealistic. Some of the businesses which did open up while BIG was running belonged to people who were not entitled to basic income grants, and some of the ventures presented as successful outcomes of BIG were found to have existed before the project was launched ${ }^{11}$.

The BIG was not connected to the aim of creating employment only and its success did not entirely depend on economic factors. But economic aspects did play an important role right from the start as they do in any kind of social welfare programme. Organisers, BIG assessors and members of the BIG Coalition repeatedly pointed out to the social and economic success of BIG (for an overview see the website of BIG Namibia and Basic Income Earth Network; see also Haarmann et al. 2009; Haarmann/Haarmann 2012; Jauch 2015), while from a purely economic point of view the project was considered to have failed (Osterkamp ${ }^{12} 2008 ; 2011 ; 2012$; 2013). After the launching of the 2009 report by Haarmann et al., those who had disapproved from the very beginning - among them influential members of Parliament - insisted that basic income grants were apparently not sustainable and wanted the project stopped. It is still to be clarified whether it was for social or economic considerations, the influence of the worldwide ideological debate over deservingness or for inner-Namibian disputes over political authority that finally turned the balance: after the 2014 national elections the idea to expand the Namibian BIG was dropped altogether, mostly for lack of political support and financial resources.

At no point in the lengthy discussion over the Pros and Cons of the Namibian BIG project has there been a reflection on the significance of cultural factors influencing the appropriation and use of income grants. "We thought that culture is not so important"13 said a member of the organising team. As could be shown later, it was exactly on these grounds that BIG did prove to be sustainable.

When I talk about "culture" in this paper, I do not mean to use the term in an essentialist way. As in any other society, there are striking differences between persons of different age, gender and social class as well as between urban and rural population. It is a truism that life is negotiated on a daily base influenced by power relations, gender disposition and individual agency. There are nevertheless practices, activities and ways of viewing the world that are shared and valued by members of social groups with more or less clear-cut group markers,

\footnotetext{
${ }^{11}$ Considering the worldwide attention to the project, it certainly would have been more favourable had some of the initiators of BIG Namibia not been involved in the evaluations and publications of the results but instead leave the field to impartial scientist altogether. Also, the research design of the evaluation did not contain long-term participant observation. Incorporating a cultural scientist into the international evaluation team and have that person stay for a while at the site of BIG would have added another perspective as well methodology and might have helped questioning some of the result.

${ }^{12}$ On behalf of the German Centre for International Migration and Development (CIM), Rigmar Osterkamp has been working as an external economist at the Namibian Economic Policy Unit (NEPRU) and the University of Namibia (UNAM) between 2007 and 2011.

${ }^{13}$ Interview with P.K., Windhoek, 8.8.2011.
} 
such as language, religion and common value. I will therefore use "culture" in the sense of a template providing codes of meaning that guide people's life and regulate their world. This neither means that everyone behaves, thinks and acts in a predictable way based on exactly the same knowledge nor would people always admit (or even know) how much their cultural base conditions behaviour. In the broadest sense, culture then refers "to the acquired, cognitive and symbolic aspects of existence" (Eriksen 2001: 4). Using the concept of culture in this way, it leaves ample space for individual differences and social diversity but does point to the fact that people have common foundations, which, if we manage to grasp them, give us a key to understanding.

\section{Research question, definitions, methods and theoretical approach}

Locations: When the anthropological fieldwork started in 2011, it was decided to do a parallel research project in the nearby settlement of Witvlei which did not receive BIG, thus serving as the contrast group. This approach promised to be fruitful for reasons of comparison and had been omitted in the first evaluation even though the ELCRN Desk for Social Development had strongly recommended it. ${ }^{14}$ The Desk was therefore only too happy to support my research.

In my view, Witvlei was most suitable as a contrast group: it is situated at a distance of approximately $50 \mathrm{~km}$ to Otjivero, far enough to impede daily contact between the inhabitants of the two settlements, which would have blurred income differences. Both settlements are situated in a rural set-up and are surrounded by mostly white-owned farmland. Even though Witvlei is a long-established village, it kept its former spatial structures. Witvlei's former black settlement (still named "the location") up to this day is inhabited by mostly poor black people. As far as the socio-economic conditions are concerned, the Witvlei location is not much different from Otjivero. The better-off part of the population lives outside the location.

The third aspect in favour of Witvlei was its cultural diversity: just as Otjivero, Witvlei location is inhabited by people of different cultural groups but with predominantly Damara background. This is exceptional to the Omaheke region where Herero speaking groups are more numerous (43\%) versus 24\% Nama/Damara speakers ${ }^{15}$ (see Suzman 1995: 4). Suzman identified the Omaheke Damara to be "the backbone of the commercial farming workforce" (1995: 4). To make comparisons easier, only persons who referred to themselves as Damara were chosen as interview partners in both places.

The reason why Witvlei had been omitted from previous research and evaluations though being the only available settlement which might have possibly served the purpose (the capital Windhoek to the west and the town of Gobabis to the east are both too large) - was the Witvlei abattoir Witvlei Meat as the then main employer (closed in 2014). The investigators regarded this source of income too significant as to leave it unconsidered and therefore claimed the Witvlei settlement was not comparable with Otjivero. ${ }^{16}$ However, a closer look at the local conditions and interviews with the management ${ }^{17}$ revealed that not all of the then

\footnotetext{
${ }^{14}$ Personal communication, Windhoek 9.8.2011.

${ }^{15}$ Since the langue of Nama and Damara shows many similarities, it is generally called "Nama/Damara".

${ }^{16}$ Personal communication.

${ }^{17}$ Interview with M. B., Witvlei, 27.9.2011.
} 
154 abattoir workers, though mostly from Witvlei and the Omaheke area, were working for Witvlei Meat on a permanent base since many of them frequently left their work place after only a few days. ${ }^{18}$ Also, none of my interview partners was working at the abattoir on a regular base. It turned out that many of the Witvlei location inhabitants had more in common with the Otjiverans than I expected: due to the very low income rates, many lived off their relatives working as farm workers on surrounding farms or as domestic workers in Windhoek who regularly provisioned their rural relatives with meat or sent money. Giving and receiving gifts turned out to be an essential part of life in both communities. Whether it was a gift from relatives or the demanded share of old peoples' pensions, a free supply of drought food (maize meal) provided by government or the remittance of a relative from outside the settlement, gifts constituted an essential part of all household incomes in both communities. Even the abattoir fitted into this pattern: on account of the abattoir management the left over and unsalable entrails such as the guts of slaughtered cattle were distributed to the inhabitants of the location on a fairly regular base. These free gifts used to be unloaded by cruising vans within the location at irregular intervals and were highly appreciated.

Taking the role of the abattoir as an economic factor into consideration, this employer on the whole was as relevant for the overall economic condition of the location's population as were the few village jobs and the Omitara farmers to the Otjivero population. It should be remembered that these farmers who caused many of the problems of the Otjivero squatters in the first place nevertheless continued to be employers offering jobs to many of them, especially those of the younger generation who regularly visited their Otjivero relatives providing meat and fat received on the farms. As opposed to the often depressing picture of helpless victims, the Otjivero inhabitants are still agents of their lives. Though living in great poverty before (and after) BIG they do know how to manage their daily survival even without a regular income just as poor people in Witvlei do. So in all respects, Witvlei did prove to be a valid contrast group and it certainly would have been benefiting had this settlement been included into the BIG project and evaluations before.

Study group: In both settlements, there are people of different ethnic affiliations such as Herero and Ovambo, few Himba and San and some of mixed ethnicity. In Otjivero, all of them qualified for the BIG independent of their cultural background. However, for the purpose of this research it looked promising to focus on just one group representing the majority of the population in both locations (Damara) for the sake of obtaining comparable data. In order to detect differences and accordance within a culturally diverse study group, a much larger research set-up would have been necessary which was not possible at that time since the BIG was already announced to be running out in 2011/2012. ${ }^{19}$

Research question: My argument was that culture has an impact on the use of income transfers as indeed on any other kind of resource. Deriving from this argument the research

\footnotetext{
${ }^{18}$ It was not evident whether the high fluctuation of workers was due to the work conditions at Witvlei Meat, the low pay of only 639 NAM /month (Sept. 2011) or to other factors that caused people quitting their jobs after a relatively short period of time.

${ }^{19} \mathrm{Had}$ additional BIG projects been realised in other parts of the country as was discussed among ELCRN and DfSD representatives in 2011 and 2012, chances would have been good to further elaborate on this kind of multi-sited research.
} 
question was formulated: What influence do cultural patterns have on the appropriation and handling of income grants? The aim was to investigate the output and sustainability of BIG.

Definitions: I use the term appropriation in the sense of Hahn as an integration of an external item or idea into one's own cultural system (Hahn 2005: 102). This implies that identical items may be received, incorporated and used differently. Following current research on the cultural dynamics of resources the term resource is applied in the sense of a "basis for or a means to create, sustain and alter social relations, units and identities within the framework of culturally affected beliefs and practices" (Bartelheim et al. 2015: 39).

Methods applied: To choose the appropriate methods for conducting the intended research, I draw on my research experience among Khoisan peoples prior to this (Klocke-Daffa $2001 ; 2003 ; 2005 ; 2008)$. Even though Damara history (still mostly unknown) is different from the history of other groups there are a number of common cultural traits all Khoisan share in particular Damara and Nama - such as language, religion, social organisation, and kinship terminology which is almost identical to that of the Nama (Barnard 1992: 206, for overview see 176-213). Many Damara today are cattle and sheep herders as the Nama are, or work in different jobs in urban and rural areas. The most striking feature shared with other Khoisan groups are closely knit social networks comprising an ongoing exchange of goods, services and persons. Being a good giver is highly estimated and increases reputation (or social capital) as well as self-esteem. Economic success is well appreciated but often neglected because social obligations come first, up to the point that the individual stands back and comes out on the short end.

Knowing that "giving" is a culturally highly appreciated value, which motivates the individual to continuously prove being a responsible social partner, I wanted to find out how the Otjivero Damara cope with an extra income grant such as the BIG which was connected to expectations (though not explicitly attached to it since BIG was supposed to be unconditional) of providing incentives to individual economic progress. The only way to get valid empirical data was to assess daily transactions over the period of at least one BIG cycle (one month) to document the process of transfers rather than catching one moment in time. Therefore, it was decided to apply a mix of anthropological methods - quantitative as well as qualitative - over a period of three months for the entire fieldwork.

a) Interview partners/survey: Within the two communities 30 households (15 in each settlement) volunteered for interviews, comprising about 350 members in total. Volunteers were chosen on a random base - in the ethnological and not statistical sense of the term - with the only two conditions that the participants should refer to themselves as heads of their households and Damara-speaking to make the results comparable. With the help of a research assistant, 29 interview partners out of 29 households (initially, 15 in each site but one later dropped out) were interviewed on a daily basis over a period of four weeks focusing on income and expenditure transfers. To find volunteers, several preliminary discussions with representatives of the two communities, church congregations and the village BIG committee (in Otjivero) were held in order to explain the research in detail. For Otjivero, there was also a member of the Desk for Social Development who at the time was monitoring the BIG payout who served as a gatekeeper and opened many doors for me. 
b) Questionnaire: As I expected, it was not feasible to calculate the exact value of each and every transferred item on an adult-equivalent basis or per capita. This was due to the ongoing exchange of items, which basically continued all day with people going in and out, asking, buying, selling, borrowing or bringing items without having been asked for. It was also owed to the fact that some items were given away where the "ownership" was not individually marked, such as maize flour pertaining to the household but freely given away by the head of the household. After intense discussions with some of my interview partners, a questionnaire was worked out which took cultural specifics into account. Rather than asking for the exact cash equivalent of daily income and expenditures, the interviewee was asked to recall the number of in- and out-transfers. They were distinguished into three categories (things given as gifts, borrowed, bought with cash; things received as gifts, borrowed things given back, and incoming cash transfers). It took three tests to have all interview partners approve the outline of the questionnaire, which then started on the day of BIG payout on 1 September 2011.

c) In-depth interviews and focus group discussions: Since the questionnaire was presented with the same questions to the same persons every day, it took less and less time for filling out. Interview partners would already be awaiting us, sitting in front of their houses inviting visitors to join in. The redundant questions facilitated the interviews and provided time for additional qualitative interviews. Also, whenever visitors were participating, listening to the questions to be answered or giving comments on how much was to be given to whom, there was a chance for a focus group discussion on general topics of my research. As most of my interview partners did not have a regular job, there was ample space for talking and gossiping. After a month of intensive interviewing, considerably more information on the general situation of each community could be obtained than would have been possible by a single inquiry. This way about 50 qualitative interviews were conducted to back up the results of the questionnaire plus some network analysis (not explicitly presented here). At the end of the field work period, roughly 700 interviews with 5000 datasets were to be evaluated (Klocke-Daffa 2012).

d) Participant observation: For the entire period of field word (three months), the researchers stayed close to the two communities. However, in Otjivero it turned out that there was no place to stay other than in one of the houses already overcrowded. The housing situation in Witvlei is slightly better and the school offered one of the guest rooms but shortly before the beginning of field work the school head decided to offer the room to one of their student interns. Following the advice of one of the BIG committee members, it was decided to rent a room on one of the surrounding farms where Otjivero people work as labourers. The farm was situated between the two communities under study, which enabled us to stay in both of them for half a day each day of field work and for special occasions on weekends like the Holy Communion. Participant observation is one of the classical anthropological methods. It is indispensable to establish a rapport with the local partners, "talking the talk" of people (DeWalt/DeWalt 2011: 41-58) and comprehend the emic point of view.

e) Critical reflection of methods used: As compared to quantitative methods used in many sociological empirical enquiries, anthropological methods have many advantages to offer as well as a few shortcomings. Stationary fieldwork, language skills and in-depth-interviews allow for a holistic perspective on cultural coherences, power relations and individual agency. This takes time. Analysis is based on long-term research findings and usually does not allow 
for big data given the fact that only relatively small samples will be selected. However, anthropologists are reluctant to confine themselves to quantitative enquiries only, which is the current method in the social sciences - even though they allow for a sophisticated set-up, selection of much larger samples, data cleaning and (quantitative) data analysis - but do not permit to answer all the questions anthropologists usually ask. Knowing how many persons do what and how they do it according to their own explanations is important and helpful in order to get the hard facts when documenting the initial situation, processes of change and the outcome of any kind of project or event as was the case in evaluating the BIG (Haarmann et al. 2009). However, mere quantitative data do not answer the question why people act and react the way they do. Also, they do not allow for explaining the cultural codes underlying individual actions, the intersections of social, religious and economic fields and particular local appropriations.

To answer these questions, a mix of quantitative and qualitative methods therefore seemed necessary and I must admit that my initial scepticism towards qualitative interviews mitigated in the course of the research. Of course, it might have been advantageous to select a bigger sample in the two study groups but it is doubtful whether the outcome would have altered the results. This research was meant to only supplement the valuable research already completed and add an additional perspective. ${ }^{20}$ Three months were considered sufficient to provide for additional insights. In any case, doing this research was only possible because of my precursory long-term experiences with Khoisan people as well as proficient language skills (Afrikaans, since most Damara are bi-lingual) to allow for interviews and group discussions without the filtering of answers by interpreters. For a profound inter- and intra-household analysis a research over a period of about one year would have been necessary, which would also have allowed considering seasonal variations, such as school vacations or Christmas, when the size of households and income/expenditure patterns might vary substantially as compared to normal months due to outgoing children visiting their parents or incoming visitors bringing extra gifts and money for the holidays. However, this would have been a different research and was not intended to be realised in the first place.

Theoretical base: Apart from the methodological foundations of anthropological research, a careful selection of theoretical approaches to analyse field data is essential to any kind of anthropological research. Only then can we hope to find a clue to understand what we observe and what is told to us. I decided to choose a theoretical approach from economic anthropology: Jonathan Parry and Maurice Bloch (1989: 23-28) elaborated the model of transactional orders postulating that in many societies two totally different orders may exist side by side: a short term cycle of transactions dominated by commodity exchange and individual economic competition, and a long-term cycle, which serves the social and cosmological reproduction of society. Analysing cash transfers thus not only requires looking into the exchange of material

\footnotetext{
${ }^{20}$ A comparison of research output in absolute numbers would have been impossible at this point of time since the monthly BIG payouts had been reduced from 100 Nam to 80 NAM which was not only lower in terms of real value but had also not been inflation adjusted. In addition, the size of households had changed due to the extra income which was one of the reasons why earlier data collection of the BIG pilot mandated by the BIG Coalition was stopped after one year - not considering the fact that the admission of extra household was precisely one of the results of BIG in view of cultural factors.
} 
items but has to consider the importance of social relationships and moral values as well. Stephen Gudemann (2005) calls it the "base" of a community.

\section{The Cultural Appropriation of BIG}

If we want to understand how the monthly allowances are handled, we have to look into some of the cultural foundations of Damara society as part of this "base". Like among other Khoisan peoples there is an elaborate exchange system, which is more than an emergency system in times of need. In Damara belief life is only possible and livable as life in exchange. So, basically anything they possess is given to and shared with others. There are few justifications for refusing to share as the norm stipulates: "You must give if you have something and somebody comes and asks you for it." Basically anything might be asked for: money and food, transport and housing, the electricity bill or a pre-paid mobile phone, childcare and personal services of almost any kind. Where people live on very scarce resources there will always be a demand for something, resulting in a continuous exchange of things, services and persons between families, households and social network partners.

Obviously, there are people who have to seek support out of sheer deprivation but there are many who ask to be given even though they are not in burning need, some send items without prior request and again others might send a gift just to return the next day and demand exactly the same back as a counter-gift. These social exchanges are highly valued and bring great respect and social reputation to any generous person. Retaining goods for individual purposes even though practiced openly as well as clandestinely is generally disapproved of if social obligations are ignored for the sake of personal interests. Those who apparently keep their possessions for themselves, who live in nicer houses, hold expensive technical equipment and private cars and refuse demands for sharing are running the risk of being called stingy. Social surveillance and gossip are powerful means of social control to ensure smooth cooperation.

However, there is more to keep individuals in line. Asked why people give so much, they answer: "I do it for the LORD". Damara have a strong belief that the LORD is the ultimate giver of anything good in life. But HE demands something back: a reciprocal gift that should be given to a third person. Refusing to share and give thus comes close to ingratitude, which might cause incalculable harm, much greater than mere damage to social reputation. Potential givers seldom appear to be annoyed (at least not openly) when asked to share even if besieged by many. Equally the beneficiaries never seem to have too much of a bad conscience when asking to share as it is them allowing the givers to be grateful towards the LORD (KlockeDaffa 2001; 2003). At the end of the day, it all pays out, because the LORD "loves the givers and gives you back double". Wealth derives from giving not keeping. Asking another person to share is therefore not at all considered to be humiliating and will even be encouraged. It keeps the system going even though not all are always willing to cooperate, some opt out and others might negotiate the price of sharing and belonging.

If we now look at the results of the research, we find that they only partially fulfilled the BIG organisers' expectations on the economic and social effects but are perfectly in line with the cultural norms and deep values of Damara society. Contrary to what was desired, people 
did not stop gift transfers. The (statistically not representative) results for the BIG-receiving settlement of Otjivero demonstrate that more than 50\% of all expenditure transfers were still conceptualised as gifts (figure 3) without stringent necessity due to the incoming extra monetary resources. Most of all transfers were given in the form of food (figure 4). It is important to bear in mind that these numbers refer to the number of transactions, not their value.

Also, an increase in gift transfers for special occasions such as rituals (confirmations, weddings and funerals) could be noted as compared to Witvlei, the settlement without BIG (figure $5)$.

Figure 3: Percentage of expenditure transfers according to dominant categories (gifts, loans, refunds, purchases, expenditures on special occasions).

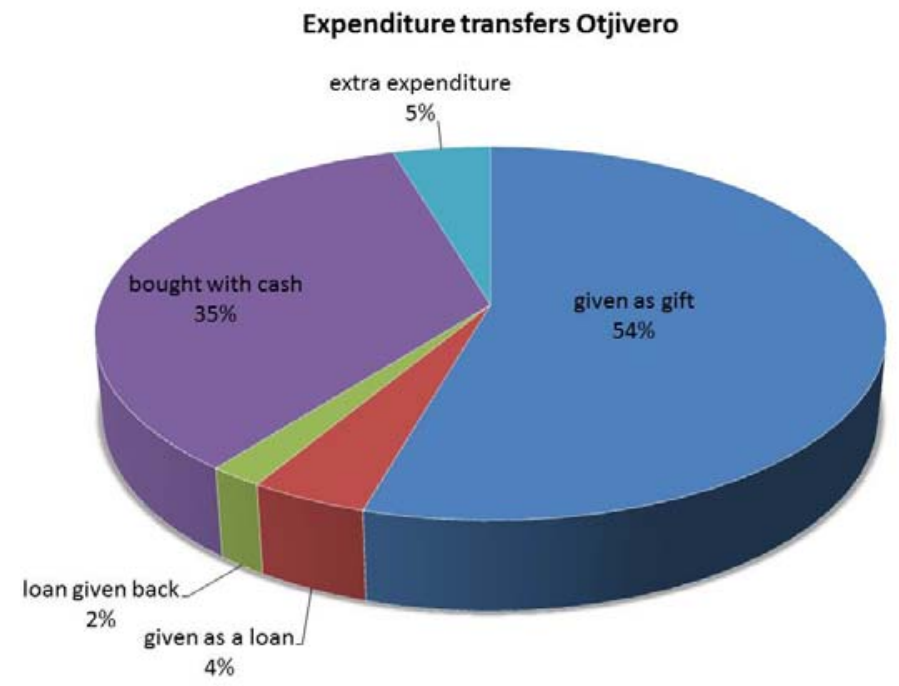

Source: S. Klocke-Daffa, evalutation by Bildungsonline 24/ M. Schlattmann

Figure 4: Percentage of expenditure transfers according to dominant type of items

Given as gift Otjivero

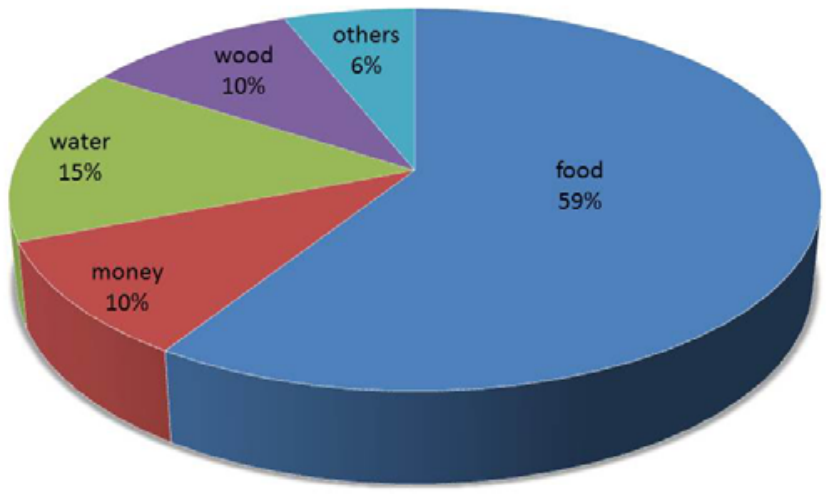

Source: S. Klocke-Daffa, evalutation by Bildungsonline 24/ M. Schlattmann 
Figure 5: Comparing number of expenditure transfers of Otjivero (with BIG) and Witvlei (without BIG)

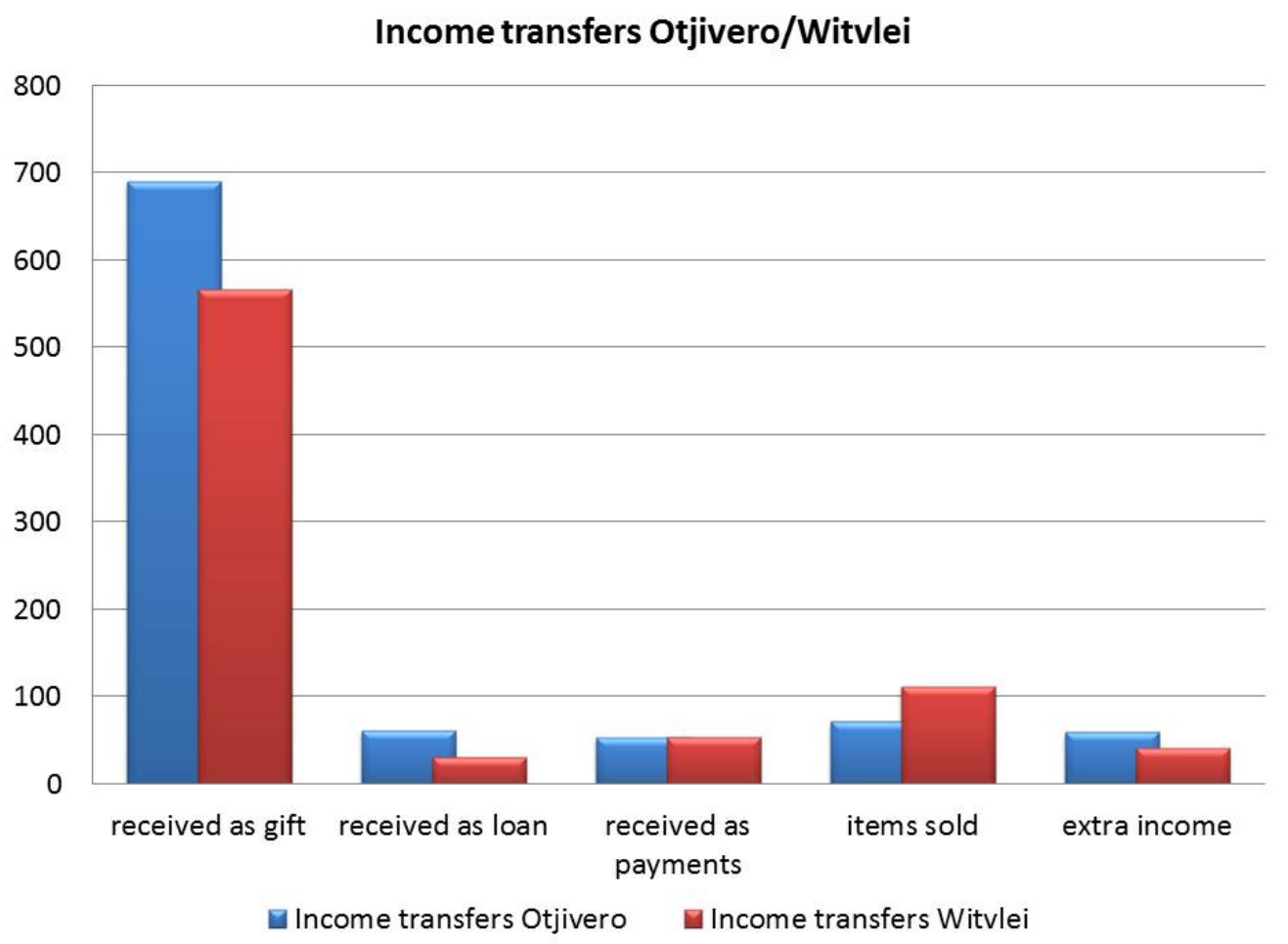

Source: S. Klocke-Daffa, evalutation by Bildungsonline 24/ M. Schlattmann

Getting back to the theoretical foundations mentioned in the beginning, we clearly see what BIG money is used for and how it is handled (figure 6):

- In a short-term cycle, BIG money is spent for commodities on the market and used for individual needs,

- but in a long-term cycle, a large part of the money and purchased commodities are fed into the existing social networks in order to guarantee the social and cosmological reproduction of society as e.g. accepting family members into the household, sharing cash income with non-beneficiaries of income grants, and donating to ritual events as a sign of gratitude towards the LORD. Concomitantly, these transfers secured the reputation of individuals as generous givers as well as the cohesion of social units.

Much to the displeasure of the project organisers and the global Pro-BIG audience, monthly grants were not used predominantly for economic entrepreneurship or for self-benefiting consumer goods but instead were fed into the more highly valued social relations whenever possible. Where BIG money did serve individual or household priorities such as buying foodstuff at the local grocery stores the beneficiaries made sure that the budget provided for enough food to be sent as a gift to needy neighbours or passing visitors. 
Figure 6: Short-term and long-term exchanges

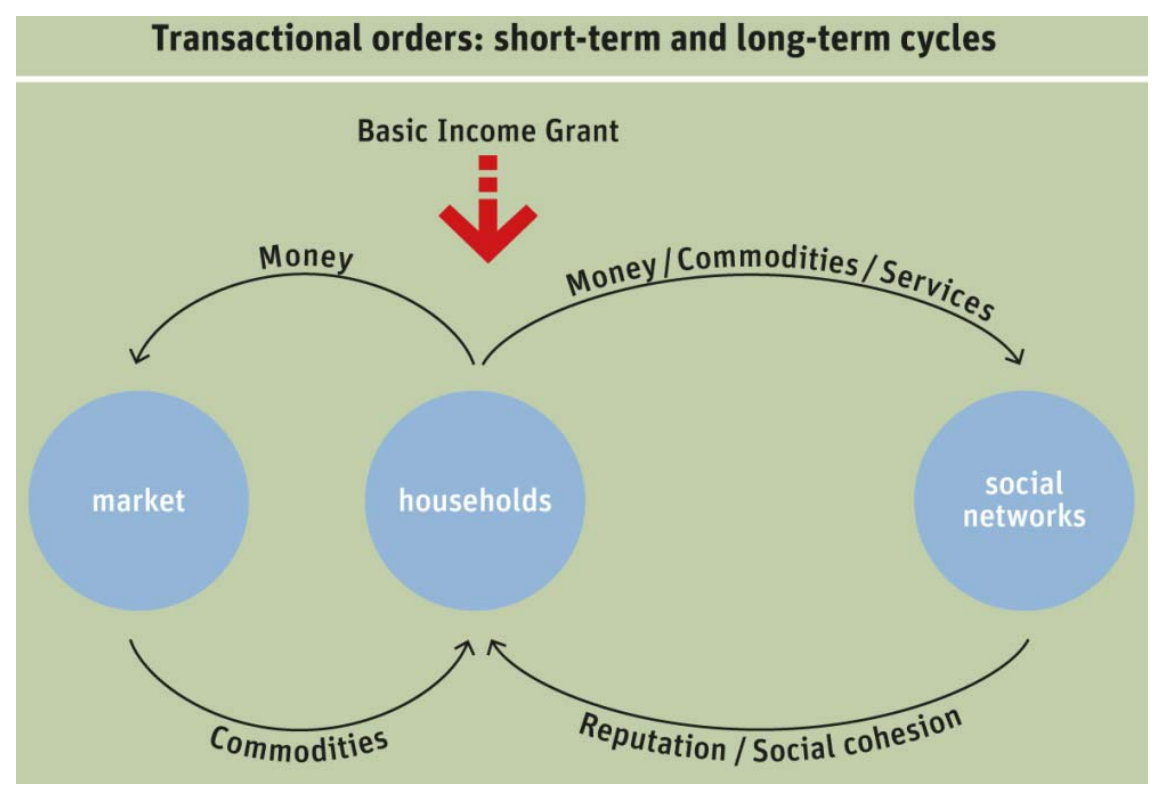

\section{Source: S. Klocke-Daffa}

Whenever resources allowed to be distributed beyond the immediate satisfaction of needs within the own household, they would be given away as becomes evident comparing the two groups (figure 7 and figure 8). In Otjivero, the pattern of transfer is almost reversed as to the one in Witvlei. The number of out-transfers in Otjivero has been consistently higher and they were more regular as compared to the relatively erratic expenditure transfers in Witvlei. The BIG payout apparently did not influence the number of income transfers in that location. What is striking is the obvious effect of old age pension payout in both settlements followed by an immediate increase in the number of transfers.

To put it in other words: cash transfers were invested in social capital and not as economic capital. From the anthropological point of view, it was interesting to find that BIG transfers were indeed conceptualised by the local population both as a kind of righteous share of the national wealth and as a gift. There was no talking about being obligated to reciprocate in preconceived ways as a kind of counter gift to a generously provided welfare gift. Quite on the contrary, beneficiaries acted much like in economies of sharing where the claim to a share of the common good neither necessitates an act of gratefulness nor does it need to be reciprocated. Representatives of the local BIG committee as well as many of my interview partners proudly presented what they had or were planning to do but never in connection with the notion of an obligation to be fulfilled towards the givers. In Witvlei, an initiative of local representatives of the Catholic Church in October 2011 was planning to send a letter to the town council demanding their share of BIG money and another letter of the bishop of the Lutheran Church to warrant their support of the BIG campaign. 
Figure 7: Expenditure transfers (blue) and incoming transfers (red) in Otjivero

Transfers Given/Received Otjivero

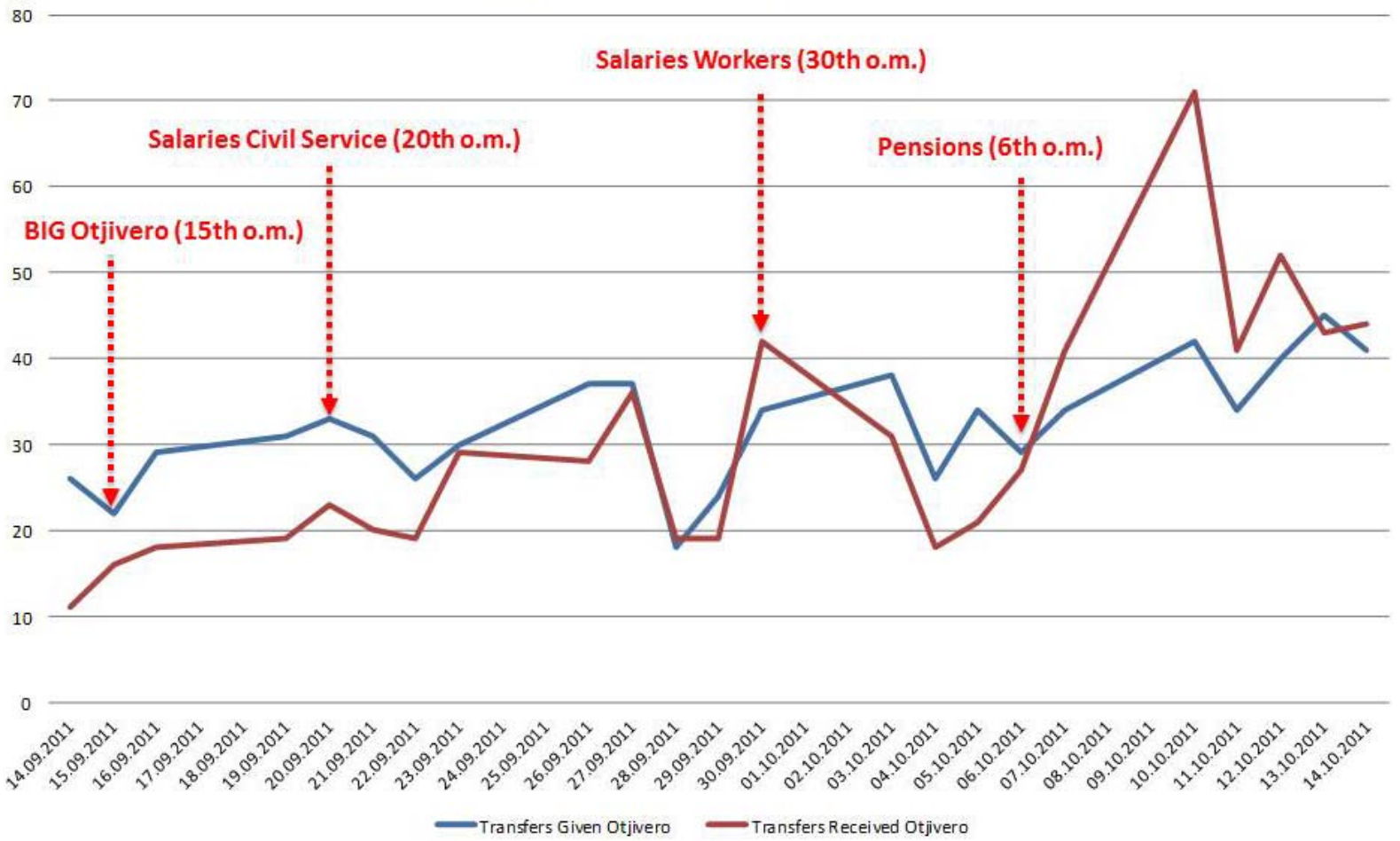

Source: S. Klocke-Daffa, evalutation by Bildungsonline 24/ M. Schlattmann

Figure 8: Expenditure transfers (blue) and incoming transfers (red) in Witvlei

Transfers Given/Received Witvlei

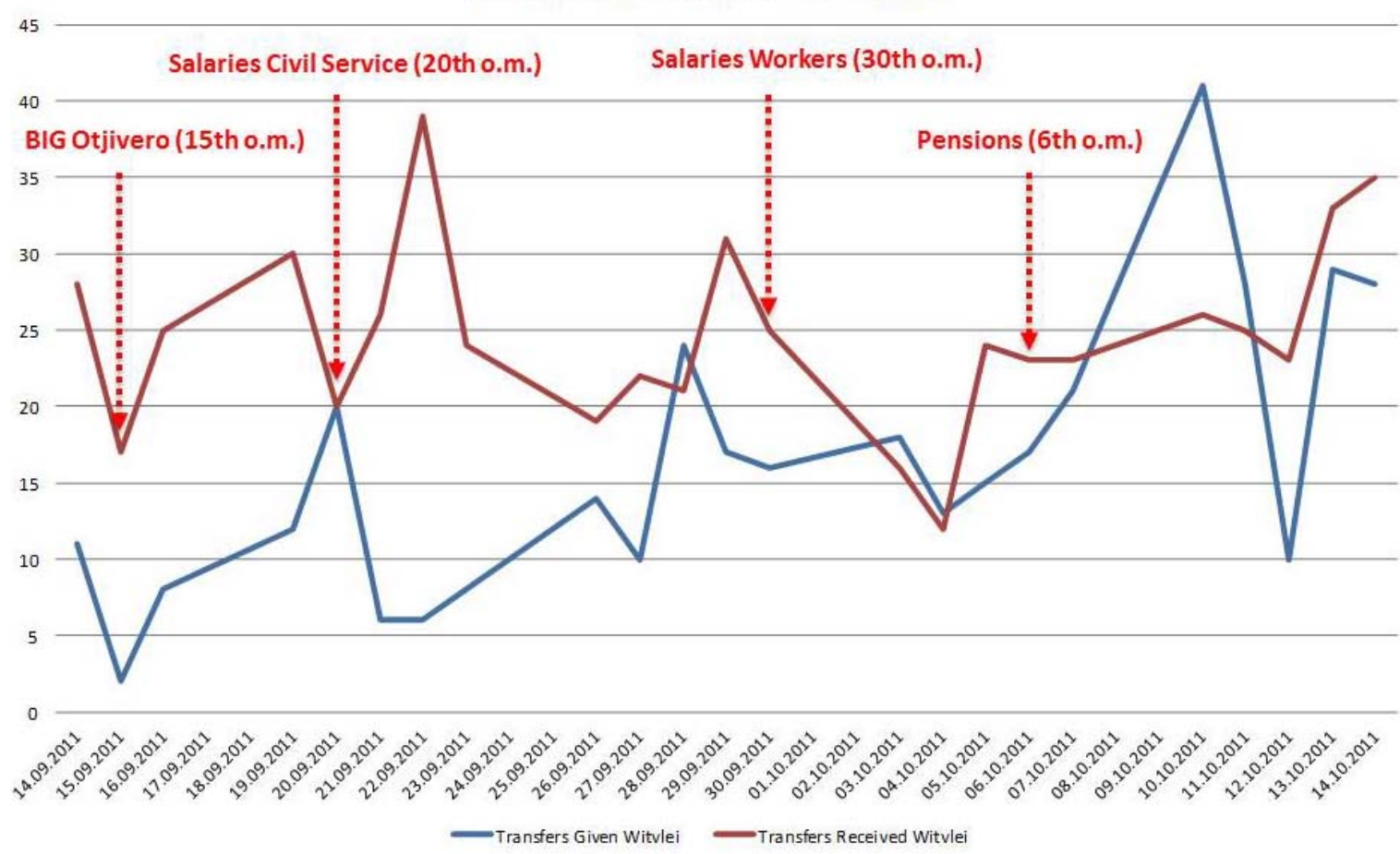

Source: S. Klocke-Daffa, evalutation by Bildungsonline 24/ M. Schlattmann 
However, in neither community was the bishop conceived of as the leading force behind the BIG nor was the Namibian government conceptualised as the big spender, donator and "giver" of money. Again and again, I was told that the bishop would only be a mediator because BIG was originally given by God who cared for the needy (and apparently also for the not so needy). Only in this respect were social benefits to be reciprocated - by giving to others. It is here where the categories of sharing and gifting are becoming blurred. Apart from the fact that we find a triadic structure of gift exchange, which might be more interesting to anthropologists than to social policy makers, it is obvious that the sustainability of unconditional basic income transfers is to be found mainly in the social sphere. Social networks not only symbolise an important part of community life but also provide a valuable asset which literally serves as a cultural resource sustaining and reproducing communities. This kind of "capital" can be referred to in times of need. Indeed, people lived off their networks every time BIG transfers were interrupted - as I could clearly detect in 2012 and 2014 when BIG was paid out only intermittently and finally stopped.

Addendum: When I revisited both communities in the summer of 2017, I expected the overall condition in Otjivero to be deteriorated due to the final stop of BIG in 2014. However, it showed that many of the school kids of the years of the BIG campaign 2007-2009 - own children or external ones who had been accepted into the households and could be sent to school on a regular base - are now working in Windhoek, Gobabis and on nearby farms, regularly sending money and food - may it be called a "gift" or a "share".

\section{Contested claims to basic income as a mechanism of social security}

If we look at the outcome of the Namibian income scheme it becomes clear that many contested claims were at stake with different political, economic and moral fields affected (Klocke-Daffa 2012). Long before the political future of BIG in Namibia was decided upon, public discourse had turned into an ideological debate with many more facets than just the unsolved problem of social justice. In fact, the ideal of justice for the poor which highlighted the early discussions on the introduction of a basic income was relegated to an issue of almost secondary importance overshadowed by the bitter competition for political authority and the best way to social welfare. Considering the public debates on basic income grants, the statements of politicians, economists and church representatives as well as the results of this research, four separate fields of contested claims can be detected. There are

1. different models of social welfare and alternate forms of social support - with the BIG competing with other social benefit schemes already in existence all based on the notion of targeting the "needy" and the "deserving" - where the social pensions for all Namibians beyond the age of 60 coming closest to a basic income scheme,

2. competing models of unconditional income grants - one being a humanitarian model based on the idea of dignity and quality of life for all versus an economic model of income grants favouring the reduction of labour costs, 
3. opposing political concepts - one being in favour of the dominant state with its ruling elite governing top-down versus a model of democratic participation of civil society influencing politics bottom-up, and

4. different notions of authority and legitimacy - one being in favour of political leaders determining what needs to be done versus the moral authority of local church leaders.

After all, the Namibian Basic income project turned out to be quite successful and could have been further expanded. The means to finance a nationwide social scheme were there as well as the organisational infrastructure. So why was it dropped? In the end, it might have all boiled down to the question of power and authority - with the Otjivero poor left to their fate. What turned the balance was the controversy between the elected representatives of the nation state and church representatives on the local and national level. When the President of State openly declared that in his view BIG would make people lazy and that it would be against the common good to expand BIG to the national level, his statement urged his followers within and outside government as well as the trade unions (also dependent on the ruling party) to abstain from supporting the scheme. Whether this was also a clash of moral and performative legitimacy as Michael Williams elaborated on contested political claims in South Africa ${ }^{21}$ (Williams 2010) would require further research. In any case, as regards the Namibian Basic Income scheme, the clash of authorities eventually sealed its fate.

\section{Conclusion: Basic Income Transfers and the quest for a rightful share}

But what does this teach us in regard to social welfare regimes in general and models of basic income in particular? When research findings of the anthropological investigation were presented to different people involved in the process of organising, monitoring or evaluating the Namibian BIG project, the responses were unexpectedly negative even though pointing to the success of BIG: most of them didn't want to hear about it. Politicians insisted that the project had failed because their concept of job creation had not been realised; economists claimed that BIG had failed because of a lack of economic stimulus; some church representatives considered BIG to be too badly equipped because it did not alleviate material poverty. From the perspective of social sciences - other than anthropology - my pointing at the cultural implications was equally met with scepticism and even charges of neo-colonialism. The only people who did accept the research findings had a Khoisan background themselves. They in turn activated their own social networks within the German Lutheran Church, which helped to continue the programme temporarily ${ }^{22}$ but could not prevent it from being stopped. Once more it became evident what Thandika Mkandawire wrote more than 10 years ago: "Ideologies play an important role in the choice of instruments used to address problems of poverty, inequality and insecurity. Each of the core concerns of policy - need, deserts and citizenship - are social

\footnotetext{
${ }^{21}$ Moral legitimacy includes the norms, values and symbols of a society defining what "adequate" political acting is. Performative legitimacy is revealed in the way how power is performed and whether power holders and citizens accord that the political system is serving the common good (Williams 2010: 20).

${ }^{22}$ After the project officially ended in 2009 and donations from international donors became more and more scarce, the German Evangelical Church in Westphalia supported BIG temporarily. http://www.moewe-westfalen.de/eine welt und entwicklungspolitik/gesundheit und soziale sicherung/basic income grant/
} 
constructs that derive full meaning from the cultural and ideological definition of 'deserving poor, entitlement and citizens' rights" (Mkandawire 2005: 2).

What this case study clearly reveals is that concepts of basic income grants are highly contested. It is obvious that there will be no final solution for the question of targeting versus universalism in poverty reduction - any regime of welfare or social transfers will have to be adapted to local and national conditions just as the views and demands of those primarily affected need to be taken into account. It also became clear that social welfare is more than a problem of political implementation and financial feasibility. For the acceptability and success of social welfare schemes, cultural factors at local levels may be equally significant as claims of legitimacy and authority at the national level.

Coming back to my arguments presented in the introduction of this paper, it proved to be indispensable to take cultural aspects of individual and collective appropriations of income transfers into consideration if we want to understand how social benefits are utilised by the beneficiaries. However, from the standpoint of the nation state, there can be no differentiation between ethnic groups, rural and urban populations and social classes in order to guarantee political equality for all its citizens. So allowing for cultural diversity in regard to the appropriation of social benefits necessitates the political intention to respect cultural diversity and individual agency even if not appreciated in all its forms. As I argued elsewhere (Klocke-Daffa 2012: 22) today's income differences may then persist, hopefully then on a higher economic level. But this argument tackles only the organisational part. The question whether an additional cultural model should be introduced into the discussion on unconditional income transfers goes deeper touching the base of our understanding of "the social". If we conceptualise social benefits not as grants and means of aid to help the needy provided by benevolent states or generous individuals but as rightful claims to the common good then the idea of what the obligations of the state are needs to be reconsidered. If anyone would be entitled to get his due share of the national wealth - whether by virtue of being a citizen or just for "being there" - we would have to get away from the idea of a gift to the "deserving" towards the idea of a "share" for everyone, get away from "help for the needy" to "making a claim to ownership". A range of societies and social groups would have no problem with changing the perspective, oscillating between gifting and sharing as demonstrated in the Namibian case. However, the existing economic model seems be only partially applicable with its narrow focus on the economic effects of basic income grants, given the cultural diversity of patterns of distribution. The humanitarian model does capture the main ideas of sharing but heavily draws on ethical principles of justice, equality, righteousness and fairness. Convincing as they are, they may still be too narrowly focusing on ethical values and there might be many who would not agree (e.g. most of my Namibian interview partners declared a basic income totally unfair if guaranteed to all but to the needy). For this reason, I still plead for the elaboration of an additional third model - be it named the cultural model or the distributional model or yet another label to be found - broad enough to incorporate emic categories of sharing and equality.

The discussion on comprehensive forms of redistribution with free, state-provided basic income transfers allowing for cultural diversity with regard to the utilisation of transfers (thus being truly unconditional on all grounds) have only just started. As James Ferguson rightly noted, "the intersection of new kinds of welfare states with new kinds of thinking about distri- 
bution has created a powerful conjunctural moment" (Ferguson 2015: 188). This will urge us to re-define and reconstruct our concepts of social welfare. In this respect, anthropological findings might provide for some helpful insights.

\section{Bibliography}

Agüero, Jorge M. (2006). The Impact of Unconditional Cash Transfers on Nutrition: The South African Child Support Grant. Accessed on 21.05.2017 at http://opensaldru.uct.ac.za/bitstream/handle/11090/46/06 08.pdf? sequence=1

Barchiesi, Franco (2007). South African Debates on the Basic Income Grant: Wage Labour and the Post-Apartheid Social Policy. Journal of Southern African Studies, 33(3), 561-575. Accessed on 20.05.2017 at http://www.jstor.org/stable/25065226.

Barnard, Alan (1992). Hunters and Herders of Southern Africa. A Comparative Ethnography of the Khoisan Peoples. Cambridge: Cambridge University Press.

Bartelheim, Martin, Roland Hardenberg, Thomas Knopf, Anke A. Scholz and Jörn Staecker (2015). ,ResourceCultures' - A Concept for Investigating the use of Resources in Different Societies. In: Danielisová, Alžběta and Manuel Fernández-Götz (eds.). Persistent Economic Ways of Living. Production, Distribution, and Consumption in Late Prehistory and Early History (39-49). Budapest: Archaeolingua Foundation.

Blaschke, Ronald (2012). Aktuelle Ansätze und Modelle von Grundsicherungen und Grundeinkommen in Deutschland. In: Blaschke, Ronald, Adeline Otto und Norbert Schepers (Hrsg.). Grundeinkommen. Von der Idee zu einer europäischen politischen Bewegung (118-251). Hamburg: VSA Verlag.

Cavaillé, Charlotte (2015). Deservingness, Self-Interest and the Welfare State: Why Some Care More about Deservingness than Others and Why It Matters. LIS Working Paper Series, No. 652. Luxembourg: Cross national Data Center.

Cheal, David (1988). The Gift Economy. London/New York: Routledge.

Davies, James, Susanne Sandström, Anthony Shorrocks and Edward Wolff (2009). The Level and Distribution of Global Household Wealth. Working Paper 15508. Cambridge, MA: National Bureau of Economic Research.

DeWalt, Kathleen M. and Billie R. DeWalt (2011). Participant observation: a guide for fieldworkers. $2^{\text {nd }}$ ed. Lanham: Alta Mira Press.

epd-Dokumentation (2009). Basic Income Grant - Grundeinkommen in Namibia, eine Herausforderung für Europa. Texte zur internationalen Fachtagung der Vereinten Evangelischen Mission gemeinsam mit der Evangelischen Kirche im Rheinland und der Evangelischen Kirche von Westfalen am 6. März in Wuppertal. epd-Dokumentation 36. Frankfurt am Main: Gemeinschaftswerk der Evangelischen Publizistik.

Eriksen, Thomas Hylland (2001): Small Places, Large Issues: An Introduction to Social and Cultural Anthropology. $2^{\text {nd }}$ ed. London: Pluto Press.

Ferguson, James (2015). Give Man a Fish. Reflections on the New Politics of Distribution. Durham/London: Duke University Press. 
Forget, Evelyn L. (2012). Canada: The Case for Basic Income. In: Murray, Matthew C. and Carole Pateman (eds.). Basic Income Worldwide: Horizons of Reform (91-101). Basingstoke: Palgrave Macmillan.

Gudeman, Stephen (2005). Community and Economy. Economy's Base. In: Carrier, James G. (ed.). A Handbook of Economic Anthropology. (95-107). Cheltenham: Edward Elgar.

Haarman, Claudia (2015). Relief through cash. Impact assessment of emergency cash grant in Namibia. Accessed on 10.11.2011 at

http://www.bignam.org/Publications/Relief through cash Impact assessment of the emergenc y_cash_grant_in_Namibia.pdf

Haarmann, Claudia, Dirk Haarmann, Herbert Jauch and Hilma Mote (2008). "Towards a basic income grant for all!" Pilot Project Assessment Report 2008. Windhoek: NANGOF.

Haarmann, Claudia, Dirk Haarmann, Herbert Jauch and Hilma Mote (2009). Making the difference! Basic Income Grant Pilot Project Assessment Report 2009. Ed. by Basic Income Grant Windhoek: NANGOF.

Haarmann, Claudia and Dirk Haarmann (2012). Namibia: Seeing the Sun Rise. The Realities and Hopes of the Basic Income Grant Pilot Project. In: Murray, Matthew C. and Carole Pateman (eds.). Basic Income Worldwide: Horizons of Reform (33-58). Basingstoke: Palgrave Macmillan.

Hahn, Hans-Peter (2005). Materielle Kultur. Eine Einführung. Berlin: Dietrich Reimer Verlag.

Hunt, Robert C. (2012). One-way economic transfers. In: Carrier, James G. (ed.). A Handbook of Economic Anthropology. (290-304). Cheltenham: Edward Elgar.

Jauch, Herbert (2015). The Rise and Fall of the Basic Income Grant Campaign: lessons from Namibia. Global Labour Journal, 6(3), 336-350.

Kaufmann, Josh (2010). BIG Hopes, BIG Questions: Namibia's Basic Income Grant. Journal of Civil Society and Social Transformation, 1, 38-46.

Klocke-Daffa, Sabine (2001)."Wenn du hast, mußt du geben". Soziale Sicherheit im Ritus und im Alltag bei den Nama von Berseba / Namibia. Studien zur sozialen und rituellen Morphologie, Bd. 3. Münster: Lit-Verlag.

Klocke-Daffa, Sabine (2003). "Der HERR ist doch gut". Zur religiösen Fundierung von Austauschbeziehungen bei Khoekhoengruppen in Namibia. In: Kramer, Dieter, Mark Münzel, Eva Raabe, Achim Sibeth, und Mona Suhrbier (ed.). Missio - Message und Museum. Festschrift für J. F. Thiel zum 70. Geburtstag. (225-236). Frankfurt: Lembeck.

Klocke-Daffa, Sabine (2005). The inheritance of social obligations among the Namibian Khoekhoen. In: Legal Assistance Centre Namibia (ed.): The meanings of inheritance. Perspectives on Namibian inheritance practices (39-45). Windhoek: Legal Assistance Centre.

Klocke-Daffa, Sabine (2008). The modernity of traditionalists. Culture change, identity and the impact of the state among the Namibian Khoekhoen. In: Biesele, Megan und Cornelia Limpricht (eds.): Heritage and Cultures in Modern Namibia: In-depth Views of the Country (174-182). Windhoek: Klaus Hess Publishers.

Klocke-Daffa, Sabine (2012). Is BIG big enough? Basic Income Grant in Namibia. An anthropological Inquiry. Tuebingen: University of Tuebingen. Accessed on 10.11 .2017 at http://tobias-lib.unituebingen.de/frontdoor.php?source opus $=6160$ 
Klöpper, Harald (2011): The BIG Confuser (in response to 'The BIG Confusion' by Kalumbi Shangula). In: The Namibian, 25.3.2011 (front page). Accesses on 12.12 .2017 at https://www.namibian.com.na/index.php?id=77731\&page=archive-read

Koistinen, Pertti and Johanna Perkiö (2014). Good and Bad Times of Social innovations: The Case of Universal Basic Income in Finland. Basic Income Studies, 9(1-2), 25-57.

Mkandawire, Thandika (2005). Targeting and Universalism in Poverty Reduction. Social Policy and Development Programme, Paper No. 23. Geneva: UNRISD.

Motte, Jochen, Theodor Rathgeber and Angelika Veddeler (eds.) (2010). Think BIG: Inputs and reflections on social justice and the basic income grant. Hannover: Foedus-Verlag.

Moyo, Tabby (2001). Namibia threatened with farm invasions. In: News Africa, 26.1.2001. Accessed at 20.10.17 https://www.iol.co.za/news/africa/namibia-threatened-with-farm-invasions-59347

Murray, Matthew C. and Carole Pateman (eds.) (2012). Basic Income Worldwide. Horizons of Reform. Basingstoke: Palgrave Macmillan.

Namibia Statistics Agency (2012). Child Poverty in Namibia. Windhoek: Namibia Statistics Agency. Accessed on 02.11.2017 at http://cms.my.na/assets/documents/p19dnb2udr1ji0d9d25sv5f124r1.pdf

Namibian Tax Consortium (2002). Report of the Namibian Tax Consortium on the Tax Structure of Namibia. Windhoek: Namibian Tax Consortium. Published on the IPPR Web Page. Accessed on 02.11.2017 at http://www.ippr.org.na/other_research.htm.

Nattrass, Nicoli and Jeremy Seekings (2005). The political economy of the basic income grant in South Africa. In: Widerquist, Karl (ed.). The ethics and economics of the basic income guarantee. (235248). Aldershot: Ashgate.

Niemann, Ingmar (2015). Grundeinkommen global - Ein Überblick über die internationalen Modellversuche zum bedingungslosen Grundeinkommen. In: Osterkamp, Rigmar (ed.). Auf dem Prüfstand: ein bedingungsloses Grundeinkommen für Deutschland? (157-168). Baden-Baden: Nomos (Zeitschrift für Politik, Sonderband 7).

Oorschot, Wim van and Femke Roosma (2017). The Social legitimacy of Targeted Welfare and Welfare Deservingness. In: Oorschot, Wim van, Tim Reeskens and Femka Roosma (eds.). The Social legitimacy of targeted welfare: Attitudes to Welfare Deservingness (3-34). Cheltenham, UK. I Northampton, USA: Edward Elgar Publishing.

Osterkamp, Rigmar (2008). Basic Income Grant - a critical analysis of the first results. NEPRU Quarterly Economic Review, 66 (September).

Osterkamp, Rigmar (2011). BIG in Namibia . Ein ernüchterndes Kapitel deutscher Entwicklungshilfe. In: Allgemeine Zeitung (Windhoek). 6.5.2011. Accessed at 12.12.2017 on

https://www.az.com.na/nachrichten/big-in-namibia-ein-ernchterndes-kapitel-deutscherentwicklungshilfe

Osterkamp, Rigmar (2012). Otjivero ohne Perspektive. In: Allgemeine Zeitung (Windhoek), 7.5.2012. Accessed at 01.11.2017 on http://www.az.com.na/lokales/otjivero-ohne-perspektive-im-dreieckdes-elends.147545.php

Osterkamp, Rigmar (2013). The Basic Income Grant Pilot Project in Namibia: A Critical Assessment. Accessed on 02.11.2017 at https://doi.org/10.1515/bis-2012-0007

Osterkamp, Rigmar (2013). Vielversprechendes Projekt zu bedingungslosem Grundeinkommen ist in Namibia gescheitert. In: Entwicklung und Zusammenarbeit $(E+Z)$, 5, 216. 
Accessed on 03.11.2017 on https://www.dandc.eu/de/article/vielversprechendes-projekt-zubedingungslosem-grundeinkommen-ist-namibia-gescheitert

Osterkamp, Rigmar (2017). Positionen: Streit um das bedingungslose Grundeinkommen: Zur aufklärenden Rolle empirischer Forschung. Sozialer Fortschritt 66(6), 451-461. Accessed at https://doi.org/10.3790/sfo.66.6.451

Parry, Jonathan and Maurice Bloch (1989). Introduction: Money and the morality of exchange. In: Parry, Jonathan and Maurice Bloch (eds.). Money and the Morality of Exchange. (1-32). Cambridge: Cambridge University Press.

Patterson, Thomas C. (2012). Distribution and redistribution. In: Carrier, James G. (ed.). A Handbook of Economic Anthropology. (194-208). Cheltenham etc.: Edward Elgar.

Petersen, Glenn (1986). Redistribution in a Micronesian Commercial Economy. Oceania 57(2), 83-98.

Robineau, Claude (1988). Reciprocity, Redistribution and Prestige among Polynesians of the Society Islands. In: Pollock, Nancy J. and Ron Crocombe (eds.). French Polynesia: A Book of Selected Readings. (181-193). Suva(Fiji): Institute of Pacific Studies of the University of the South Pacific.

Seekings, Jeremy and Heidi Matisonn (2012). The Continuing Politics of Basic Income. In: Murray, Matthew C. and Carole Pateman (eds.). Basic Income Worldwide: Horizons of Reform. (128-150) Basingstoke: Palgrave Macmillan.

Standing, Guy and Michael Samson (2003). A basic income grant for South Africa. Lansdowne: University of Cape Town Press.

Straubhaar, Thomas (2008). Bedingungsloses Grundeinkommen und Solidarisches Bürgergeld - mehr als sozialutopische Konzepte. Hamburg: Hamburg Univ. Press.

Suplici, Eduardo Matarazzo (2003). Legitimizing Basic Income in Development countries: Brazil, or: "The answer is blowin' in the wind". Journal of Post Keynesian Economics, 25(3), 407-424.

Suzman, James (1995). Poverty, Land and Power in the Omaheke Region. Windhoek: Oxfam.

UNDP United Nations Development Programme (2000). Human Development Report. Accessed at http://hdr.undp.org/en/content/human-development-report-2000

UNDP United Nations Development Programme (2016a): Human Development Report. Income Gini Coefficient. New York: UNDP. Accessed on 29.10.2017 at

http://hdr.undp.org/en/content/income-gini-coefficient

UNDP United Nations Development Program (2016b). Human Development Reports. Accessed at 30.10.2017 on http://hdr.undp.org/sites/default/files/2016 human development report.pdf

Van der Veen, Robert J. (1998). Real Freedom versus Reciprocity: Competing Views on the Justice of Unconditional Basic Income. Political Studies, 46, 140-163. Accessed on 30.10.2017 on http://onlinelibrary.wiley.com/wol1/doi/10.1111/1467-9248.00134/abstract

Van Langendonck, Jef (2007). The Meaning of the Right to Social Security. In: Van Langendonck, Jef (ed.). The Right to Social Security (3-12). Antwerpen/Oxford: Intersentia.

Van Parijs, Philippe (1992). Arguing for Basic Income. Ethical Foundations for a Radical Reform. London/New York: Verso.

Van Parijs, Philippe (1995). Real Freedom for All. New York: Oxford University Press.

Van Parijs, Philippe (2000). A Basic Income for All. If you really care about freedom, give people an unconditional income. The Boston Review, Oct./Nov. 2000. Accessed on 12.12.2017 at http://bostonreview.net/archives/BR25.5/vanparijs.html\#10 
Van Parijs, Philippe and Yannick Vanderborght (2017). Basic Income. A radical Proposal for a Free Society and a Sane Economy. Cambridge, Massachusetts/ London, England: Harvard University Press.

Widlok, Thomas (2017). Anthropology and the Economy of Sharing. London: Routledge.

Williams, Michael J. (2010). Chieftaincy, the state, and democracy. Bloomington: Indiana University Press.

Wood, Geof and Ian Gough (2006). A Comparative Welfare Regime Approach to Global Social Policy. World Development, 34(10), 1696-1712.

Woodburn, James (1998). 'Sharing is not a form of reciprocitiy': An Analysis of Property Sharing in Immediate-Return Hunter-Gathering Societies. In: Hann, Chris M. (ed.). Property Relations: Renewing the Anthropological Tradition (48-63). Cambridge: Cambridge University Press.

Wright, Erik O. (2000). Reducing Income and Wealth Inequality: Real Utopian Proposals. Contemporary Sociology, 29(1), 143-156. Accessed on 02.11.2017 at http://www.jstor.org/stable/2654939

Yan, Yunxiang (2012). The gift and gift economy. In: Carrier, James G. (ed.). A Handbook of Economic Anthropology (262-274). Cheltenham etc.: Edward Elgar.

\section{Websites}

Basic Income Canada: http://basicincome.org/news/2017/03/ontario-canada-government-releasesresults-consultations-basic-income-pilot/

Basic Income Earth Network: http://www.basicincome.org/bien/

Basic Income Finland: http://money.cnn.com/2017/01/02/news/economy/finland-universal-basicincomel

Basic Income Grant Namibia: http://www.bignam.org/

Basic Income Initiative Germany: http://www.grundeinkommen.de

Basic income initiative Switzerland: http://www.grundeinkommen.ch/

Basic Income Namibia: www.big-namibia.org

Basic Income: www.basicincome.org

Evangelical Church of Westphalia / Germany:

http://www.moewe-westfalen.de/eine welt und entwicklungspolitik/gesundheit und soziale

sicherung/basic income grant/

Evangelische Vereinigte Mission (Evangelical United Mission Wuppertal): www.vemission.org/big

Namibia Statistics Office Publications: http://nsa.org.na/

United Nations Development Programme 2016: Human Development Reports. Accessed on http://hdr.undp.org/en/content/income-gini-coefficient

World Bank: https://data.worldbank.org/country/namibia 